\title{
Haplotypes inside the beta-globin gene: use as new biomarkers for beta-thalassemia prenatal diagnosis in north of Iran
}

\author{
Mohammad Bagher Hashemi-Soteh ${ }^{1,3^{*}}$, Seyed Saeed Mousavi ${ }^{2}$ and Alireza Tafazoli,
}

\begin{abstract}
Background: Beta-thalassemia is common in the Mediterranean area as well as the Middle East and India. Official report in Iran revealed the average prevalence rate of carriers about 4\%. More than 20 restriction fragment length polymorphisms (RFLPs) are known in the beta-globin gene cluster and used in the prenatal diagnosis (PND) services. Some of these locations may have low allele frequency and are not informative in the prenatal diagnosis. The current study aims to find new haplotypes and polymorphisms with high allele frequency in the local population.

Methods: Two thousand three hundred fifty samples (1,321 male and 1,029 female) from the northern Iran, whom suspected to be the carriers either for alpha or beta thalassemia and referred to the local diagnostic laboratory as a routine services were investigated during five years, (2010-2015). The beta-globin gene was sequenced for all samples.

Results: Heterozygosity for five SNPs in the beta-globin gene was calculated separately. 383 individuals (16.29\%) showed no sign of nucleotide change in the beta-globin gene sequence. In total, codon2 (C/T) 31.72\%, IVSII-16 (C/G) 31.72\%, IVSII74 (G/T) 54.71\%, IVSII-81 (C/T) 19.47\%, and IVSII-666 (T/C) 31.72\% were seen respectively. Although all five polymorphisms showed reasonably high heterozygosity, IVSII-74 (G/T) [GG wild type (36.5\%), G/T (54.71\%) and TT (8.8\%)] revealed the highest heterozygosity rate. Four combinations of these five SNPs were defined as new haplotypes named M1 to M4. ARMS-PCR also were designed and applied to detect IVSII-74 (G/T) nucleotide position.
\end{abstract}

Conclusions: This study represents an intragenic polymorphism, IVSII-74, a reliable position with high heterozygosity rates in Iranian population for PND analysis.

Trial registration: Retrospectively registered.

Keywords: Beta-thalassemia, Beta-globin gene, Haplotypes, Prenatal diagnosis, Mazandaran

\section{Background}

Thalassemia is a highly prevalent genetic disorder across Asia and some parts of Europe. Beta-thalassemia is more common in the Mediterranean area as well as the Middle East and India [1, 2]. An official report from the Genetics Office in Iran's Ministry of Health and Medical Education (GO-MOH) reveal that the average prevalence rate of thalassemia carriers in Iran is about 4\%, varying at different provinces with the highest rate of

\footnotetext{
* Correspondence: hashemisoteh@mazums.ac.ir

${ }^{1}$ Immunogenetic Research Center, Molecular and Cell biology Research Center, Medical Faculty, Mazandaran University of Medical Sciences, Sari, Mazandaran, Iran ${ }^{3}$ Department of Biochemistry, Biophysics and Genetics, School of Medicine, Mazandaran University of Medical Sciences, Farahabad Road, P.O. Box. 481751665 , Sari, Mazandaran, Iran

Full list of author information is available at the end of the article
}

9.5\% in Kerman and the lowest 1\% in West Azerbaijan. Mazandaran, with a carrier rate of more than $8.0 \%$, is also among the provinces with a high rate $[3,4]$. According to the statistical data published by the Iranian thalassemia association, over 18,000 affected patients are living in the country. About 2500 among them are registered in the Mazandaran province. Prenatal diagnosis (PND) of thalassemia has been possible in Iran since 1992 [5]. A national prevention and treatment program for thalassemia was implemented in 1997. It is now wellestablished and known as one of the screening programs in the world [6].

Informative polymorphisms are important in prenatal diagnosis to differentiate between normal and mutant gene inheritance from parent to child [7]. More than 20 
Table 1 Specific primers were designed for DNA sequencing of coding regions in the beta-globin gene. Besides, the primers were designed to genotyping of IVSII-74 (rs7480526) by the ARMS-PCR methods

\begin{tabular}{llll}
\hline Primer name & Primer Sequence & $\begin{array}{l}\text { PCR size } \\
(\mathrm{bp})\end{array}$ & $\begin{array}{l}\text { Annealing } \\
\text { temperature }\end{array}$ \\
\hline HBB 1F & GTA GCA ATT TGT ACT GAT GGT & & \\
& ATG G & & \\
HBB 2R & CT CCA CAC TGA TGC AAT CAT TC & 861 & $63^{\circ}$ \\
HBB 3F & ATG TAT CAT GCC TCT TTG CAC C & & \\
HBB 3R & GCA CTG ACC TCC CAC ATT CC & 578 & $63^{\circ}$ \\
IVSII-74 N & TTA AGT TCA TGT CAT AGG AAG & & \\
& GTG AG & & \\
IVSII-74 M & TTA AGT TCA TGT CAT AGG AAG & & \\
& GTG AT & & \\
IVSII-74 R & ATC ACT GTT ATT CTT TAG AAT & 589 & $60^{\circ}$ \\
GAPDH F & GGT GC \\
GAPDH R & GGT TGA GCA CAA GGA GTA AG & & \\
\hline
\end{tabular}

restriction fragment length polymorphisms (RFLPs) are known in the beta-globin gene cluster and some of them are routinely used in the PND services [8-10]. Most of these RFLPs are located out of the beta-globin gene (HBB), somewhere upstream or downstream in the beta-globin cluster $[9,10]$. Some of these locations may have low allele frequency in the local population and are not informative in the prenatal diagnosis [11-14]. Besides, a hotspots point for meiotic recombination is known to be upstream of the beta-globin gene $[15,16]$. Hence, this study aims to find new polymorphisms and haplotypes with high allele frequencies in the local population and, preferably, inside the beta-globin gene in order to use in linkage analysis in the prenatal diagnoses. A fairly large number of samples were sequenced and studied in this research.

\section{Methods}

\section{Sample collection}

A cross-sectional study on 2350 samples (1321 male and 1029 female) from the Mazandaran and Golestan provinces of Iran whom suspected to be the carriers either for alpha or beta thalassemia and referred to the local diagnostic laboratory as a routine services were investigated during five years, (2010-2015). These individuals had reduced hematological indices (MCV lower than $80 \mathrm{ft}$. and $\mathrm{MCH}$ lower than $27 \mathrm{Pg}$ ).

All peoples with microcytic and/or hypochromic condition that is tested in this study was not patient (e.g. beta-thalassemia major). Instead, the samples were included beta or alpha-thalassemia carriers as well as peoples with no mutations, because a part of the people with microcytic and hypochromic condition may not reveal any mutation in alpha/beta genes (up to $20 \%$ in our study). So the sample in this study was included affected alleles (beta-thalassemia carriers) as well as non affected alleles (beta-thalssemia carriers, alpha-thalassemia carriers and people with no mutation).

They were nominated for genetic tests as a part of the national screening program for the prevention of thalassemia [5]. All the individuals had signed consent forms for participating in this research project.

\section{DNA extraction and PCR amplification}

A 5 to $10-\mathrm{ml}$ blood sample was taken into an EDTA containing tube. The lymphocytic genomic DNA was isolated according to a previously published method [17]. Two sets of primers were used to amplify the betaglobin gene (HBB) (Table 1). Briefly, beta-globin gene was amplified by $200 \mathrm{mM}$ dNTP, $1 \mathrm{U}$ Taq DNA polymerase (Cinagen, Iran), 1× Taq buffer, 20 pM each primer, $1.5 \mathrm{mM} \mathrm{MgCl} 2$ and $1 \mu \mathrm{l}(300 \mathrm{ng}$ ) of DNA were mixed and the volume was adjusted to $25 \mu \mathrm{l}$ with water. Amplifying a $861 \mathrm{bp}$ and a $578 \mathrm{bp}$ fragment were initially denatured at $95{ }^{\circ} \mathrm{C}$ for one minute, followed by 35 cycles of denaturation at $95{ }^{\circ} \mathrm{C}$ for $60 \mathrm{~s}$, annealing for $60 \mathrm{~s}$, and extension at $72{ }^{\circ} \mathrm{C}$ for $60 \mathrm{~s}$ and a final extension at $72{ }^{\circ} \mathrm{C}$ for $5 \mathrm{~min}$. The samples were then subjected to a final extension step at $72{ }^{\circ} \mathrm{C}$ for $5 \mathrm{~min}$. A $6-\mu \mathrm{l}$ aliquot of each PCR product was run on a $1 \%$ flatbed agarose gel to check for positive amplification $[6,18]$.

\section{DNA sequencing and genotyping}

Beta-globin gene was sequenced for all individuals as a part of the diagnostic genetic laboratory service and protocol. Two specific primer sets were applied to amplify the beta-globin gene (Table 1), followed by Sanger sequencing methods. Beside the mutation detection as normal diagnostic services, genotyping also was carried out for the five common polymorphisms including codon2 $(\mathrm{C} / \mathrm{T})$

Table 2 Prevalence of SNP heterozygosity for five polymorphisms found among the people in the northern provinces of Iran

\begin{tabular}{|c|c|c|c|c|c|c|}
\hline \multirow{2}{*}{$\frac{\text { Polymorphic position }}{\text { Codon } 2(C / T)}$} & \multirow{2}{*}{$\begin{array}{l}\text { Accession number } \\
\text { rs63750898 }\end{array}$} & \multicolumn{3}{|c|}{ Genotype frequency (\%) } & \multicolumn{2}{|c|}{ Allele Frequency (\%) } \\
\hline & & CC (64.72) & CT (31.72) & $\Pi(3.5)$ & C (79.78) & $\mathrm{T}(20.22)$ \\
\hline IVSII-16 (C/G) & rs63750254 & CC (64.72) & CG (31.72) & GG (3.5) & C (79.78) & $G(20.22)$ \\
\hline IVSII-74 (G/T) & rs7480526 & GG (36.5) & GT (54.71) & $\Pi(8.8)$ & G (62.78) & $\top(37.22)$ \\
\hline IVSII-81(C/T) & rs7946748 & CC (78.68) & $\mathrm{CT}(19.47)$ & $\Pi(1.81)$ & C (91.09) & $\mathrm{T}(8.90)$ \\
\hline IVSII-666(T/C) & rs1609812 & ТT (64.72) & $\mathrm{TC}(31.72)$ & CC (3.5) & $\mathrm{T}(79.78)$ & $C(20.22)$ \\
\hline
\end{tabular}




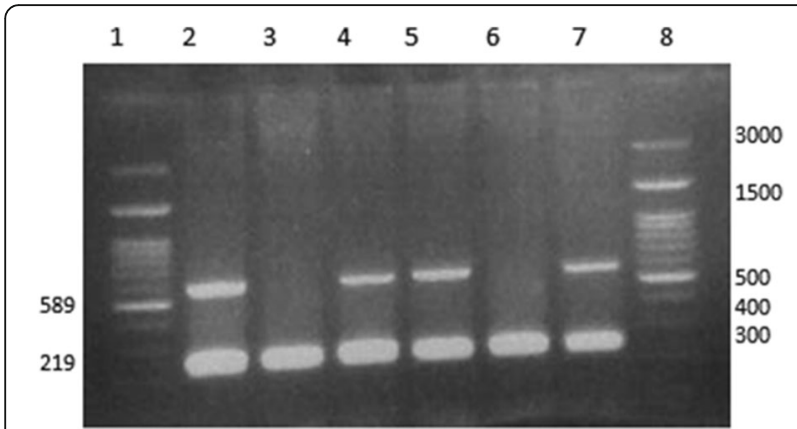

Fig. 1 ARMS-PCR for IVSII-74 (G > T) polymorphism. Lane 2 and 3 belong to a normal individual $(\mathrm{T} / \mathrm{T})$, lane 4 and 5 belong to a heterozygous individual (T/G), lane 6 and 7 belong to a homozygous (G/G) individual, lanes 1 and 8 are a 100 bp DNA ladder

(rs63750898), IVSII-16 (C/G) (rs63750254), IVSII-74 (G/ T) (rs7480526), IVSII-81 (C/T) (rs7946748) and IVSII-666 (T/C) (rs1609812) for each individual (Table 2).

\section{ARMS-PCR for IVSII-74 (G > T)}

Three specific primers, including one normal (IVSII74-N), one mutant (IVSII74-M), and a common reverse primer (IVSII74-R), were designed (Table 1) in order to genotype of the IVSII-74 position. The PCR product was $589 \mathrm{bp}$ long. Also a set of primers was used to amplify a DNA fragment in Glyceraldehyde 3-phosphate dehydrogenase (abbreviated as GAPDH) as an internal control (Table 1 and Fig. 1). The PCR product for internal control was 219 bp long. The following PCR conditions were applied: $95^{\circ} \mathrm{C}$ for $10 \mathrm{~min}$, followed by 35 cycles at $94{ }^{\circ} \mathrm{C}$ for $45 \mathrm{~s}$, $60{ }^{\circ} \mathrm{C}$ for $60 \mathrm{~s}$, and $72{ }^{\circ} \mathrm{C}$ for $60 \mathrm{~s}$, finishing with a cycle for $10 \mathrm{~min}$ at $72{ }^{\circ} \mathrm{C}$. Around $10 \mu \mathrm{l}$ of PCR product were then run on $1 \%$ agarose gel for electrophoresis and analysis of the bands (Fig. 1).

\section{Results}

Around 2350 individuals (1321 male and 1029 female) were studied. Five different polymorphisms in the beta-globin gene were analyzed using direct DNA sequencing method. Table 2 showed the genotype and allele frequency of five common polymorphisms in the beta-globin gene found in the northern provinces of Iran. In this study, the SNP heterozygosity was calculated separately for each five polymorphism. The codon2 (C/T) statistics showed 31.72\%,
IVSII-16 (C/G) 31.72\%, IVSII-74 (G/T) 54.71\%, IVSII-81 $(\mathrm{C} / \mathrm{T}) \quad 19.47 \%$, and IVSII-666 (T/C) 31.72\%, respectively. Although all five polymorphisms showed reasonably high heterozygosity, IVSII-74 (G/T) [GG wild type (36.5\%), G/T (54.71\%) and TT (8.8\%)] showed the highest heterozygosity rate in this study (Table 2).

The genotype distribution of 5 single nucleotide polymorphisms (SNPs) was analyzed for Hardy-Weinberg equilibrium (HWE). From 5 SNPs, 4 were compatible, except IVSII-74 $(\mathrm{G}>\mathrm{T})$ which did not show compatibility with HWE.

An association of these five polymorphisms was studied as four different haplotypes, named M1 to M4, which earlier defined as "beta-globin framework" (Table 3) [13]. As many as $63.91 \%$ of alleles showed no sign of these five nucleotide changes in the beta-globin gene sequence at the indicated locations and the nucleotides were matched with haplotype M1 sequence (Table 3). The remaining alleles were M2 with $16.75 \%$, M3 with $11.74 \%$ and M4 with $7.6 \%$ frequency respectively. Compared to M1 as the major haplotype in population, M3 haplotype has nucleotide changes in all five polymorphisms (Table 3).

\section{Discussion}

Two routinely-applied main approaches for prenatal diagnosis include mutation detection or the direct method and linkage analysis using polymorphic sites as a DNA marker, also known as the indirect method are normally applied in our diagnostic genetic laboratory [19]. Meanwhile, over 20 SNPs for restriction enzymes have been recognized in the beta-globin gene cluster so far [8-10]. Most of these sites have a low frequency among the Iranian population and are relatively far from the beta-globin gene $[12-14,20]$. Only a few are near or inside the betaglobin gene, including the $\beta$-RsaI, $\beta$-AvaII, and $\beta$-hinfI restriction sites [21]. There is also a hot spot for recombination near the $5^{\prime}$ end of the beta-globin gene. So, there is a possibility of mistake in detecting mutated allele through linkage analysis $[15,16]$. In order to increase the accuracy of the indirect mutation analysis, the evaluation of new SNPs and their use in the molecular analysis of beta-thalassemia are investigated in this study.

Five polymorphisms have recently been reported in the beta-globin gene in the Iranian population [13]. Akhavan Niaki and colleagues reported the RFLP restriction

Table 3 Frequency of four different haplotypes, named M1 to M4 investigated in this study

\begin{tabular}{llllllll}
\hline Haplotype & Codon 2 & IVS2-16 & IVS2-74 & IVS2-81 & IVS2-666 & Frequency (\%) $^{\text {Framework }^{\text {a }}}$ \\
\hline M1 & C & C & G & C & T & 63.91 & Framework 1 \\
M2 & C & C & T & C & T & 16.75 & Framework 2 \\
M3 & T & G & T & T & C & 11.74 & Framework 3 \\
M4 & T & G & T & C & C & 7.6 & Framework 3a \\
\hline
\end{tabular}

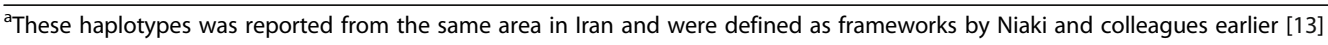


digestion for some of these polymorphic loci, including Codon2 (C/T) (rs63750898) recognized by HgiAI, IVSII16 (C/G) (rs63750254) recognized by AvaII, and IVSII-666 (T/C) (rs1609812) recognized by SspI [13]. In their study of 211 Mazandarani individuals using SspI restriction enzyme in PCR-RFLP method on IVSII-666 polymorphic site, the relevant frequency of $14.3 \%$ was reported [13]. In the current study, we evaluated five common polymorphisms in the beta-globin gene in 2350 individuals. Our results indicated the frequency of $31.72 \%$ for codon $2(\mathrm{C} /$ T), 31.72\% for IVSII-16 (C/G), 54.71\% for IVSII-74 (G/T), $19.47 \%$ for IVSII- $81(\mathrm{C} / \mathrm{T})$, and finally, $31.72 \%$ for IVSII$666(\mathrm{~T} / \mathrm{C})$ respectively (Table 2$)$. This research also indicates that the IVSII-74 $(\mathrm{G} / \mathrm{T})$ polymorphism has the highest frequency among the people from the northern parts of Iran.

Different restriction sites mainly outside the beta-globin gene (HBB) sequence are used now by a diagnostic genetic laboratory in haplotype analysis. We proposed IVSII-74 (G/T) as a polymorphism located in the HBB gene with high heterozygosity rates in Iranian population as a new haplotype marker. A simple ARMS-PCR method also has been established to genotype this polymorphism in different individuals in this study (Fig. 1).

A frequency of 4 different haplotypes as we called M1 to M4 included five different polymorphisms in the HBB gene are shown in Table 3. Niaki and her colleagues have also defined these 4 haplotypes as frameworks earlier [13]. The frequency of the haplotypes achieved in this study was different with those reported earlier from the same area because of the sample sizes. The sample size in this study was 2350 individuals from the general population compared with 46 thalassemia patients investigated before [13]. Haplotype M1, which has no nucleotide changes in any five polymorphic sites, registered the highest frequency at $63.91 \%$ and the haplotype M4 with nucleotide change in 4 different polymorphic positions out of 5 , registered the lowest at $7.6 \%$ (Table 3 ).

This research introduced a new intragenic position which can be used along with previously known markers in the PND diagnostic services. Also, along with IVSII74, other intragenic polymorphisms such as IVSII-81 with high heterozygosity rate $(19.47 \%)$ in the northern population of Iran could prove to be better candidate markers for the prenatal analysis compared with the previously known markers outside the HBB gene.

\section{Conclusion}

This is the first study with a relatively large number of participants (2350 individuals) on the beta-globin gene polymorphisms in the Mazandaran and Golestan provinces of Iran. Using IVSII-74 polymorphism with high heterozygosity along with the previously known markers in PND services is recommended.

\section{Abbreviations}

GAPDH: Glyceraldehyde 3-phosphate dehydrogenase; GO-MOH: Genetics Office in Iran's Ministry of Health and Medical Education; HBB: beta-globin gene; PND: Prenatal diagnosis; RFLPs: Restriction fragment length polymorphisms

\section{Acknowledgements}

The authors acknowledge all thalassemia patients, who participated in this study voluntarily, Novin Genetics Laboratory staffs, and the Mazandaran University of Medical Sciences.

\section{Funding}

This project supported by Novin Genetics Laboratory financial grant.

\section{Availability of data and materials}

All data generated or analysed during this study are included in this published article.

\section{Authors' contributions}

"MBHS designed the study plan, supervised all parts of this project, interpreted the patient data, and did the final edition of the manuscript. SSM performed all the experiments and registered the results. AT helped in performing the experiments, gathered and collected the relevant data, and wrote the manuscript draft. All authors read and approved the final manuscript."

Ethics approval and consent to participate

This study was approved by the ethics committee (IRB) of Mazandaran University of Medical Sciences (MAZUMS).

\section{Consent for publication}

All the individuals had signed consent forms for participating in this research project and use the obtained data in relevant publications.

\section{Competing interests}

The authors declare that they have no competing interests.

\section{Publisher's Note}

Springer Nature remains neutral with regard to jurisdictional claims in published maps and institutional affiliations.

\section{Author details}

${ }^{1}$ Immunogenetic Research Center, Molecular and Cell biology Research Center, Medical Faculty, Mazandaran University of Medical Sciences, Sari, Mazandaran, Iran. ${ }^{2}$ Novin Genetics diagnostic laboratory, Farah Abad 4, Farah Abad Boulevard, Sari, Mazandaran, Iran. ${ }^{3}$ Department of Biochemistry, Biophysics and Genetics, School of Medicine, Mazandaran University of Medical Sciences, Farahabad Road, P.O. Box. 481751665, Sari, Mazandaran, Iran. ${ }^{4}$ Medical Genetics Research Center, Mashhad University of Medical Sciences, Mashhad, Iran.

Received: 25 July 2017 Accepted: 21 November 2017

Published online: 04 December 2017

\section{References}

1. Weatherall DJ. Thalassemia as a global health problem: recent progress toward its control in the developing countries. Ann N Y Acad Sci. 2010; 1202:17-23.

2. Ostrowsky JT, Lippman A, Scriver CR. Cost-benefit analysis of a thalassemia disease prevention program. Am J Public Health. 1985;75(7):732-6.

3. Strauss BS. Genetic counseling for thalassemia in the Islamic Republic of Iran. Perspect Biol Med. 2009;52(3):364-76.

4. Miri M, Tabrizi Namini M, Hadipour Dehshal M, Sadeghian Varnosfaderani F, Ahmadvand A, Yousefi Darestani S, et al. Thalassemia in Iran in last twenty years: the carrier rates and the births trend. IJBC. 2013;6(1):11-7.

5. Abolghasemi H, Amid A, Zeinali S, Radfar MH, Eshghi P, Rahiminejad MS, et al. Thalassemia in Iran: epidemiology, prevention, and management. J Pediatr Hematol Oncol. 2007;29(4):233-8.

6. Samavat A, Modell B. Iranian national thalassaemia screening programme. BMJ. 2004;329(7475):1134-7.

7. Old JM, Ayyub H, Wood WG, Clegg JB, Weatherall DJ. Linkage analysis of nondeletion hereditary persistence of fetal hemoglobin. Science. 1982; 215(4535):981-2. 
8. Orkin SH, Kazazian HH Jr, Antonarakis SE, Goff SC, Boehm CD, Sexton JP, et al. Linkage of beta-thalassaemia mutations and beta-globin gene polymorphisms with DNA polymorphisms in human beta-globin gene cluster. Nature. 1982; 296(5858):627-31.

9. Old JM, Petrou M, Modell B, Weatherall DJ. Feasibility of antenatal diagnosis of beta thalassaemia by DNA polymorphisms in Asian Indian and Cypriot populations. Br J Haematol. 1984;57(2):255-63.

10. Antonarakis SE, Kazazian HH Jr, Orkin SH. DNA polymorphism and molecular pathology of the human globin gene clusters. Hum Genet. 1985;69(1):1-14.

11. Rahimi Z, Merat A, Akhzari M, Haghshenass M, Nagel RL, Gerard N, et al. Beta-globin gene cluster haplotypes in Iranian patients with beta-thalassemia. IJHOBMT-international journal of hematology-oncology and. Bone Marrow Transplant. 2005;2(6):3-034.

12. Rahimi Z, Muniz A, Akramipour R, Tofieghzadeh F, Mozafari H, Vaisi-Raygani A, et al. Haplotype analysis of beta thalassemia patients in western Iran. Blood Cells Mol Dis. 2009;42(2):140-3.

13. Akhavan-Niaki H, Banihashemi A, Azizi M. Beta globin frameworks in thalassemia major patients from north iran. Iran J Pediatr. 2012;22(3):297-302.

14. Derakhshan S, Khorrami A, Feizi A, Khaniani M. Spectrum of $\beta$-globin gene mutations and $\beta$-thalassemia HaplotypeAnalysis among the Iranian Azeri Turkish population. Epidemiology (sunnyvale). 2015;5(210):2161-1165.1000210.

15. Chakravarti A, Buetow KH, Antonarakis SE, Waber PG, Boehm CD, Kazazian $\mathrm{HH}$. Nonuniform recombination within the human beta-globin gene cluster. Am J Hum Genet. 1984;36(6):1239-58.

16. Old JM, Heath C, Fitches A, Thein SL, Jeffreys AJ, Petrou M, et al. Meiotic recombination between two polymorphic restriction sites within the beta globin gene cluster. J Med Genet. 1986;23(1):14-8.

17. Hashemi Soteh M, Peake IR, Marsden L, Anson J, Batlle J, Meyer D, et al. Mutational analysis of the von Willebrand factor gene in type 1 von Willebrand disease using conformation sensitive gel electrophoresis: a comparison of fluorescent and manual techniques. Haematologica. 2007;92(4):550-3.

18. Hashemi-Soteh SM, Sarzare F, Merat F, Salehifar E, Shiran MR. Frequencies of three CYP2D6 nonfunctional alleles (CYP2D6*3, *4, and *6) within an Iranian population (Mazandaran). Genet Test Mol Biomarkers. 2011:15(11):821-5.

19. Tantravahi $U$, Wheeler P. Molecular genetic testing for prenatal diagnosis. Clin Lab Med. 2003;23(2):481-502.

20. Moradi T, Vallian R, Fazeli Z, Haghighatnia A, Vallian S. Heterozygosis deficit of polymorphic markers linked to the beta-globin gene cluster region in the Iranian population. Iran J Basic Med Sci. 2015;18(6):571-5.

21. Semenza GL, Dowling CE, Kazazian HH Jr, Hinf I. Polymorphism 3' to the human beta-globin gene detected by the polymerase chain reaction (PCR) Nucleic Acids Res. 1989;17(6):2376.

\section{Submit your next manuscript to BioMed Central and we will help you at every step:}

- We accept pre-submission inquiries

- Our selector tool helps you to find the most relevant journal

- We provide round the clock customer support

- Convenient online submission

- Thorough peer review

- Inclusion in PubMed and all major indexing services

- Maximum visibility for your research

Submit your manuscript at www.biomedcentral.com/submit

) Biomed Central 